\title{
New records to three Neotropical primates to Minas Gerais and Mato Grosso States and small expansion of occurrence area to Cebus libidinosus Spix, 1823
}

\author{
Aloysio Souza de Moura ${ }^{1}$ \\ Felipe Santana Machado² \\ Bruno Senna Corrêa ${ }^{3}$ \\ Marco Aurélio Leite Fontes ${ }^{4}$
}

\section{Abstract}

Recent compiled papers demonstrate several gaps in occurrence records and distribution limits mainly due to information deficiency, hindering the management and planning of preservation and conservation efforts. Therefore, the objective of this study is to present and analyze new records of four Neotropical Primates species: Callicebus moloch, Mico emiliae, Ateles marginatus and Cebus (Sapajus) libidinosus. Data collection was assessed by interviews, census on pre-existing trails and direct observations. The expeditions took place in the cities of Pains (Minas Gerais state), Serra do Salitre (Minas Gerais state) and Guarantã do Norte (Mato Grosso state). Mico emilie, C. moloch and A. marginatus were recorded in Guarantã do Norte and C. libidinosus was recorded in Serra do Salitre and Pains. A small expansion of occurrence area to $C$. libidinosus was observed. We recommend new mammal inventories in order to understand the faunal diversity in these areas and propose new conservation actions.

Keywords: Distribution; Primates of the New World; Updated records.

\section{Introduction}

In Brazil the primate order has a total of 118 species and represents $16.8 \%$ of the total mammal species (PAGLIA et al., 2012). This representation is directly related to the vast expanse of tropical forests that present favorable environment (AYRES et al., 2005). Some primate species suffer a reduction in their populations in response to human actions in their environment while others tend to adjust and adapt to changes at certain levels (TERBORGH, 1986).

A significant number of species of Neotropical primates is listed by International Union for Conservation of Nature (IUCN) as critically endangered (13.62\%) or lack of data (4.23\%) (IUCN, 2014). Primate conservation plans are developed for species or groups of species summarizing the knowledge of these data to build action plans (BLAIR et al., 2013).

Recent compiled papers demonstrate several gaps in occurrence records and distribution limits (e.g. GREGORIN et al., 2010) mainly due to information deficiency, hindering the management and planning of preservation and conservation efforts. Therefore, our intention is to present primate records to locations where there are no mammalian studies, adding new records to these locations.

\footnotetext{
1 Universidade Federal de Lavras (UFLA), Departamento de Ciências Florestais - DCF, mestrando. thraupidaelo@yahoo.com.br. PO Box 3037, Lavras (MG), Brazil, Zip Code: 37200-000.

2 Universidade Federal de Lavras (UFLA), Departamento de Ciências Florestais - DCF, doutor. epilefsama@hotmail.com.

3 Centro Federal de Educação Tecnológica de Minas Gerais (CEFET/MG), professor. brunocorrea@nepomuceno.cefetmg.br.

4 Universidade Federal de Lavras (UFLA), Departamento de Ciências Florestais - DCF, professor. fontes@dcf.ufla.br.
} 
The aim of this study is to present the new records of three Neotropical primate species: Callicebus moloch (Hoffmannsegg, 1807), Mico emiliae (Thomas, 1920) and Ateles marginatus (E. Geoffroy, 1809) and expand the geographic range of Cebus (Sapajus) libidinosus Spix, 1823. The records in this paper are for the states of Minas Gerais and Mato Grosso. Both states have an important diversity from a conservationist point of view since the Cerrado and Atlantic Forest biomes are within them (MYERS; MITTERMEIER, 2000). These biomes are threatened mainly by the fragmentation and degradation of habitat and by the introduction of exotic species, which has the potential to endanger endemic and non-endemic species.

\section{Materials and methods}

The sampling focused on three areas: Guarantã do Norte (Mato Grosso state), Serra do Salitre and Pains (Minas Gerais state). The landscape of Guarantãa do Norte is composed of seasonal forests, rainforests with palm trees, secondary vegetation, coffee and soybeans areas, grazing areas, riparian forests and Brazilian Savannah ("Cerrado campo sujo" in the Brazilian classification). Climate is represented by two distinct seasons: rainy summers $(2.750 \mathrm{~mm}$ average) with higher intensities from January to March and dry winters with little variation in temperature, with an annual average of $26^{\circ} \mathrm{C}$, which is similar to typical tropical climate (Aw Koppen classification) (ALVARES et al., 2013).

The landscape of Serra do Salitre consists of Cerrado sensu-strict, fragments of semideciduous forests, grasslands, plantation areas (Eucalyptus, coffee, corn and beans, predominantly) and manmade areas.

The region of Pains is part of the karst region of Arcos, Pains and Doresopolis (ZAMPAULO, 2010). It is located in the karstic province of Bambuí, which is represented by an extensive metasedimentary cover composed of a mega pelitic of Neoproterozoic age (DARDENNE, 1978). Surrounding areas are composed of seasonal forest fragments, riparian forests, disturbed areas, farming areas (coffee, corn and beans, predominantly) and fragments of deciduous forest on limestone outcrops.

We interviewed local residents and government agencies (INSTITUTO BRASILEIRO DO MEIO AMBIENTE E DOS RECURSOS NATURAIS RENOVÁVEIS - IBAMA), censuses in pre-existing trails and direct observations with photographic records in order to gather the data. Interviews were applied to fifteen local hunters, who served as guides to locate the forests, which were inventoried by the census day method. During the interviews, we used both scientific and common names (RABELO et al., 2014).

The census occurred along pre-existing trails that were randomly selected for all areas. The first expedition was in Pains (Minas Gerais state) during the rainy (February) and dry (June) seasons in 2005 (six field days each). The second expedition happened in Serra do Salitre (Minas Gerais state) during the rainy season (April) in 2009 (six field days). The third expedition was in Guarantã do Norte (Mato Grosso state) during the rainy season (November) in 2011 (twelve field days). Five cameras-trap were used in Serra do Salitre, with a sampling effort of 30 traps-day. The cameras were disposed in a linear transect and the distance between them was five kilometers.

The identification of $C$. moloch, $M$. emiliae and $A$. marginatus followed a description of external features and distributions of localities, which was based on Gregorin et al. (2011) study. The description of C. libidinosus followed Gutiérrez and Marinho-Filho (2017). 


\section{Results}

The record of $C$. libidinosus (Figure $1 \mathrm{~A}$ ) was performed by direct observation in the field and examination of photos of a small group located in an adjacent riverine semi-deciduous forest fragment located in an intermediate stage of regeneration in Serra do Salitre. The record of $C$. libidinosus was performed by direct observation of one group and by photos taken by a camera trap used for records of medium and large mammals (Figure 2B, 2C, 2D, 2E and 2F). The camera trap was placed in the middle of a seasonal deciduous forest fragment around the karst meso region in Pains (Figure 3).

Figure 1. Records of Cebus (Sapajus) libidinosus (1A), Callicebus moloch (1B) and Mico emiliae (1C and 1D).

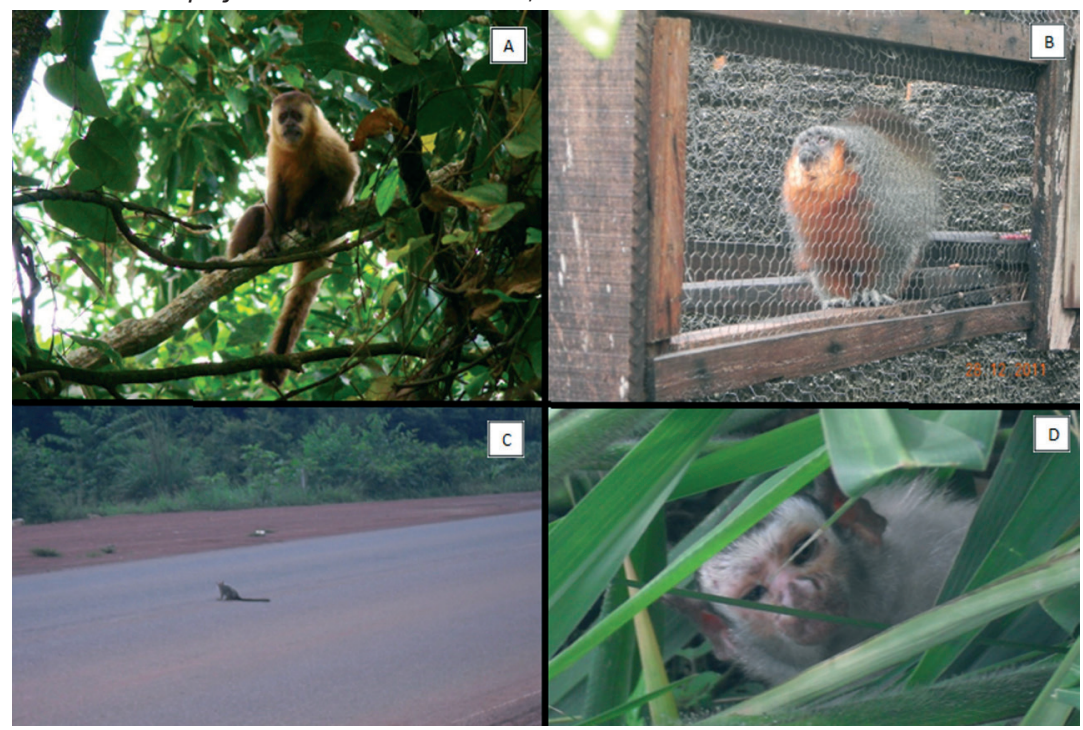

Source: elaborated by the authors. Photos taken and made available by Aloysio S. de Moura.

Figure 2. Records from camera traps of Ateles marginatus (1A), Cebus libidinosus (2B, 2C, 2D, 2E and 2F) in natural areas.

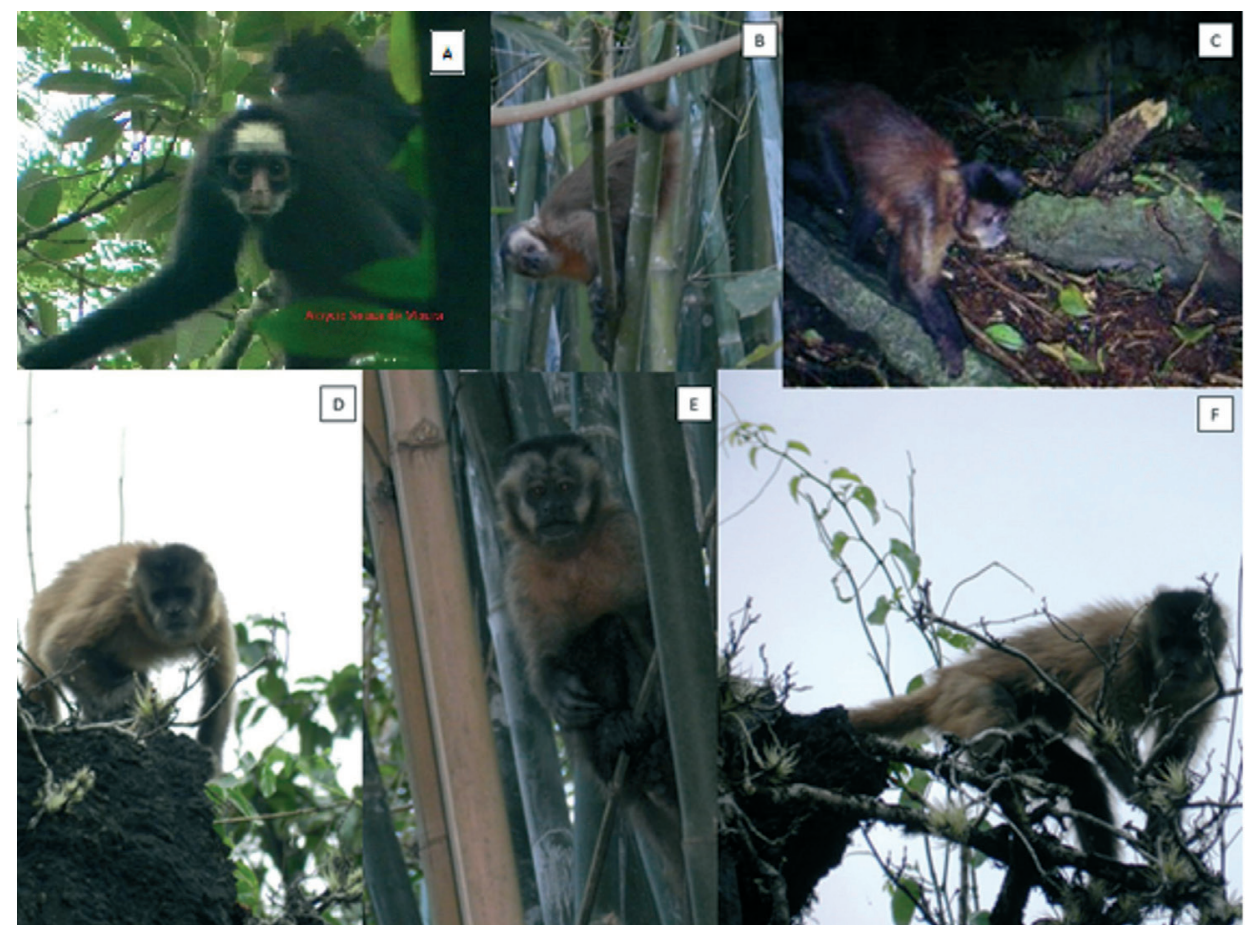

Source: elaborated by the authors. Photos taken and made available by Aloysio S. de Moura. 
The record of $C$. moloch was obtained through a visit to IBAMA in Guarantã do Norte (Figure 1B). The individual was reintroduced in the river spring of Serra do Cachimbo Biological Reserve (Protected Area). Considering there is a proposed division in Serra do Cachimbo National Park and the Environmental Protection Area Vale of XV, IBAMA volunteers captured the animal in an area reported as the Porcão River in Guarantã do Norte (Figure 3).

The record of $M$. emiliae (Figure $1 C$ and 1D) was performed by direct observation and photographic record. The individual was registered while crossing the highway BR PA 163, near the city limits of Guarantã do Norte (Figure 3).

The record of $A$. marginatus was performed by direct observation and photographic record (Figure 2A). The individual was recorded during the day in one of the censuses conducted in the region surrounding the river spring of Serra do Cachimbo Biological Reserve in Guarantã do Norte (Figure 3). The visualized group had six individuals and the photographic record shows a female with an infant on her back.

Figure 3. Maps of distribution areas for Callicebus moloch (3A), Ateles marginatus (3B), Cebus libidinosus (3C) and Mico emiliae (3D). The dots represent the cities and the new records. The gray area represents the occurrence sites. The city in Mato Grosso state is Gurantã do Norte. The southernmost city in Minas Gerais state is Pains and the other is Serra do Salitre.

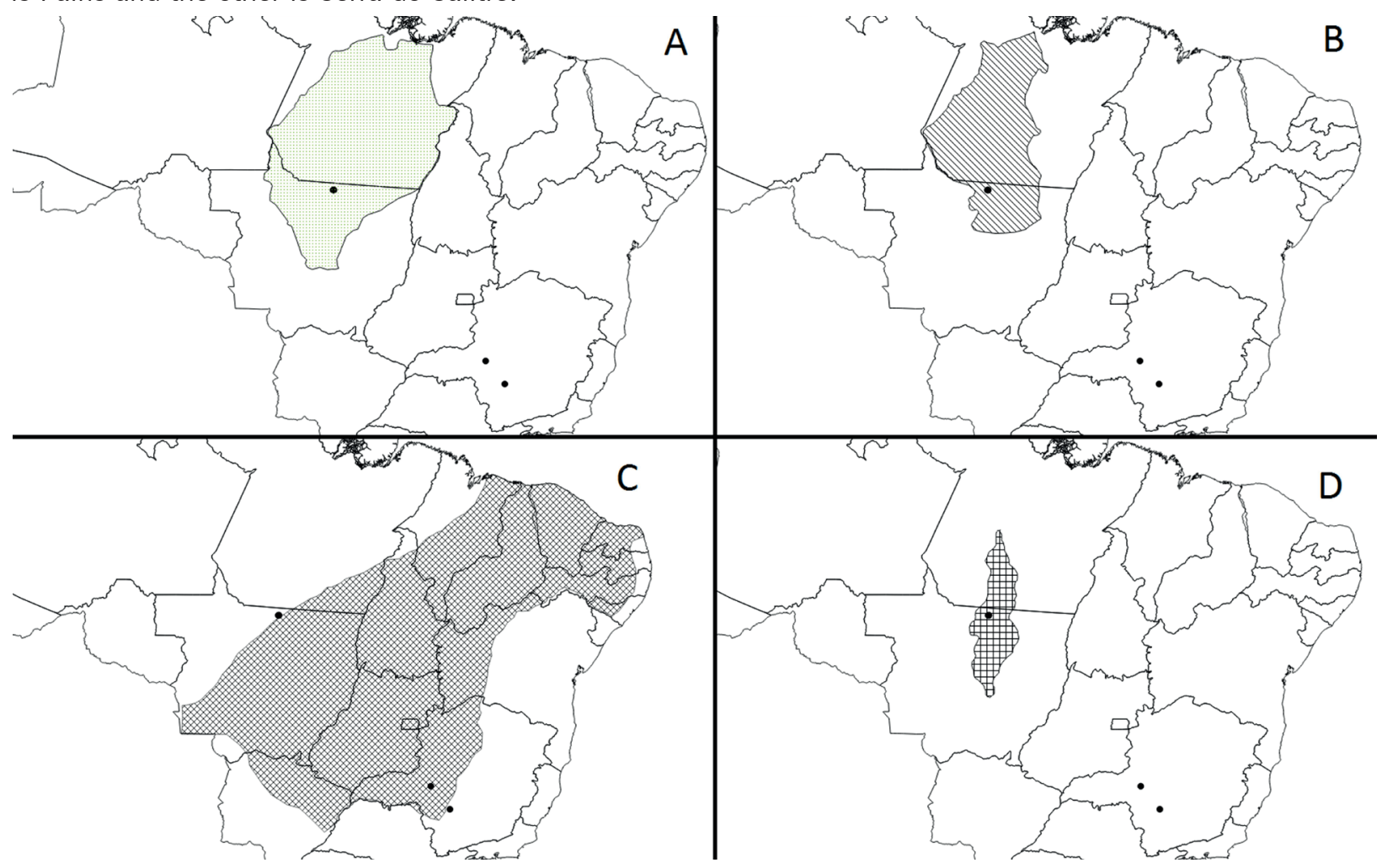

Source: Maps from Qgis, locations obtained by the authors and distribution area (hatched) provided by IUCN.

\section{Discussion}

There is little concern regarding the conservation status of Cebus (Sapajus) libidinosus (Cebidae), but there is a population reduction trend. The southern limit of its geographic range is Bambuí, in the state of Minas Gerais. This study presents an occurrence site $40 \mathrm{~km}$ away from the distribution (Pains city) according to IUCN (RYLANDS; KIERULFF, 2015). The observation in Serra do Salitre city 
is within the current distribution of the species, but this paper presents the first record since there is no published data related to mammal registries.

Pains region is exalted by researchers because of its underground biological relevance (ZAMPAULO, 2010). However, the non-speleological biological diversity requires further study. This work presents new records for rare primates that were not previously mentioned in the scientific literature. The geology and vegetation of Serra do Salitre is similar to Pains region. The gap in the current mammal studies demands further efforts aiming at providing the scientific community with records that can increase future mammal conservation programs.

Callicebus moloch (Pitheciidae) presents little concern regarding its conservation status (VEIGA; FERRARI, 2015). The record of $C$. moloch is within the range of the species, with observations of $C$. moloch in Porto Esperança city, Mato Grosso state and in Santarém city, Pará state in the south of the Amazon River (IUCN, 2008).

Mico emiliae (Cebidae) literature record is deficient regarding its ecology and biology (RYLANDS; SILVA, 2015). Pimenta and Silva Junior (2005) recorded some groups of Mico emiliae in Serra do Cachimbo, Pará state, and in Peixoto de Azevedo city, Mato Grosso state. However, Fialho (2010) recorded a group on the left bank of the Teles Pires river, in Jacareacanga city, Pará state. Therefore, this article increases the number of records of the Mico emiliae (Cebidae) species.

Ateles marginatus (Atelidae) was considered in the 80s (KONSTANT et al., 1985; MITTERMEIER et al., 1989) as one of the most endangered South American primates, given that their distribution is restricted to areas impacted by human activities (Martins et al., 1988). Recent classifications show it as "endangered" with a trend toward population reduction (MITTERMEIER et al., 2008). The species was recorded in north and west of Pará state, west of the low Tocantins river, east of the Tapajós and in Teles Pires river (AURICCHIO, 1995). The northern white-cheeked spider monkey records are restricted to the region of Santarém, Pará state (West), Altamira, Pará state (Southeastern) and Santarém, Pará state (Northeastern) (MITTERMEIER et al. 2008). This paper increases the number of records of the species. The importance of the forest fragments of Guarantã do Norte city goes far beyond the primate records herein reported. Moura et al. (2012) mention an observation of one of the most powerful predators of the Neotropics: Harpia harpyja. State intervention in the preservation of flagship species is necessary. Vegetal and animal species richness, endemisms and rare records are indicative of the necessity of biodiversity centers.

We conclude the cities in which the primates described in this paper were recorded need mammalian inventories for full knowledge of local wildlife diversity. We present three new records: $C$. moloch, M. emiliae and $A$. marginatus; we also present a small expansion of the area of occurrence for C. libidinosus.

\section{Acknowledgements}

The authors gratefully acknowledge Claudia Guimarães Costa, José de Souza e Silva Junior (Cazuza) and Fabiano R. de Melo for providing important information about primates' biology and the IUCN for providing the maps of distribution. 


\section{Novos registros de quatro primatas neotropicais para os estados de Minas Gerais e Mato Grosso}

\section{Resumo}

Recentes compilados demonstram algumas lacunas nos registros de ocorrência e limites de distribuição de primatas principalmente devido a informações deficientes, dificultando o planejamento e manejo de ações preservacionistas e conservacionistas. Portanto, o objetivo deste artigo é apresentar e analisar novos registros de quatro espécies de primatas Neotropicais; Callicebus moloch, Mico emiliae Ateles marginatus e Cebus (Sapajus) libidinosus. Os métodos de coleta de dados foram entrevistas, censos em trilhas pré-existentes e observações diretas. As expedições aconteceram nas cidades de Pains (Minas Gerais), Serra do Salitre (Minas Gerais) e Guarantã do Norte (Mato Grosso). Mico emilie, C. moloch e A. marginatus foram registrados em Guarantã do Norte e C. libidinosus na Serra do Salitre e Pains. É apresentada uma pequena expansão para área de ocorrência de C. libidinosus. Nós recomendamos novos inventários de mamíferos para entender a diversidade faunística nessas cidades e propor novas ações conservacionistas.

Palavras-chave: Distribuição. Primatas do Novo Mundo. Registros atualizados.

\section{References}

ALVARES, C. A.; STAPE, J. L.; SENTELHAS, P. C.; MORAES, G. de; LEONARDO, J.; SPAROVEK, G. Köppen's climate classification map for Brazil. Meteorologische Zeitschrift, v. 22, n. 6, p. 711-728, 2013. Disponível em: <http://docserver.ingentaconnect.com/deliver/connect/schweiz/09412948/ v22n6/s8.pdf?expires $=151759841$ 9\&id $=0000 \&$ titleid $=1292 \&$ checksum $=182$ B508C9FC9F69D34296CE7D803114E>. Acesso em: 02 fev. 2018.

AURICCHIO, P. Primatas do Brasil. São Paulo: Terra Brasilis, 1995.

AYRES, J. M.; FONSECA, G. A. B.; RYLANDS, A. B.; QUEIROZ, H. L.; PINTO, L. P.; MASTERSON, D.; CAVALCANTI, R. B. Os corredores ecológicos das florestas tropicais do Brasil. Belém: Sociedade Civil Mamirauá, 2005.

BLAIR, M. J.; BYNUM, N.; STERLING, E. J. Determining conservation status and contributing to in situ conservation action. In: STERLING, E. J.; BYNUM, N.; BLAIR, M. J. (eds.). Primate Ecology and Conservation: A handbook of techniques. Oxford University Press, 2013. p. 278-293.

BRASIL. Portaria n 444, de 17 de dezembro de 2014. Lista Nacional Oficial das Espécies da Fauna Ameaçadas de Extinção. Diário Oficial [da] República Federativa do Brasil, Poder Executivo, Brasília, DF, 18 dez. 2014. Seção 1, p. 121-126. Disponível em: <http://www.icmbio.gov.br/portal/images/ stories/biodiversidade/fauna-brasileira/avaliacao-do-risco/PORTARIA\%C2\%BA_444_DE_17_DE_DEZEMBRO_DE_2014.pdf>. Acesso em: 27 jun. 2015.

DARDENNE, M. A. Síntese sobre a estratigrafia do Grupo Bambuí no Brasil Central. In: CONGRESSO BRASILEIRO DE GEOLOGIA, 30, 1978, Recife. Anais... Recife: [s.n.], v. 2, 1978, p. 597-610. 
FIALHO, M. S. Contribuição à distribuição do Género Mico, (Callitrichidae, Primates) no Médio Teles Pires, Jacareacanga, Pará. Neotropical Primates, v. 17, n. 1, p. 31-32, 2010. Disponível em: <http://www.bioone.org/doi/pdf/10.1896/044.017.0101>. Acesso em: 02 fev. 2018.

GREGORIN, R.; SIMOES, S. A. M.; LIMA, I. J.; SILVA JUNIOR, J. S. E. Ordem Primates. In: REIS, N. R.; PERACCHI, A. L.; FREGONEZI, M. N.; ROSSANEIS, B. K. (Eds.). Mamíferos do Brasil. Guia de Identificação. Rio de Janeiro: Technical Books Editora, 2010. p. 101-211.

GUTIÉRREZ, E.; MARINHO-FILHO, J. The mammalian faunas endemic to the Cerrado and the Caatinga. ZooKeys, v. 644, p. 105-157, 2017. Disponível em: <https://www.ncbi.nlm.nih.gov/pmc/ articles/PMC5242261/pdf/zookeys-644-105.pdf>. Acesso em: 02 fev. 2018.

INTERNATIONAL UNION FOR CONSERVATION OF NATURE - IUCN. Callicebus moloch. The IUCN Red List of Threatened Species. Version 2015.2. 2008. Disponível em: <www.iucnredlist.org $>$. Acesso em: 27 jun. 2015.

INTERNATIONAL UNION FOR CONSERVATION OF NATURE - IUCN. Red List of Threatened Species. Version 2013.2., 2014. Disponível em: <www.iucnredlist.org>. Acesso em: 27 jun. 2015.

KONSTANT, W.; MITTERMEIER, R. A.; NASH, S. D. Spider monkeys in captivity and in the wild. Primate Conservation, v. 5, p. 82-109, 1985.

MARTINS, E. S.; AYRES, J. M.; VALLE, M. B. R. On the status of Ateles belzebuth marginatus with notes on other primates of the Iriri River Basin. Primate Conservation, v. 9, p. 87-90, 1988.

MITTERMEIER, R. A.; KINZEY, W. G.; MAST, R. B. Neotropical primate conservation. Journal of Human Evolution, v. 18, p. 597-610, 1989. Disponível em: <https://ac.els-cdn.com/0047248489900961/1s2.0-0047248489900961-main.pdf?_tid=7e01dd30-083a-11e8-bfcd-00000aacb360\&acdnat $=1517590975 \_4$ ecdc6130a7f650c5d1d07905669c1af >. Acesso em: 02 fev. 2018.

MITTERMEIER, R. A.; BOUBLI, J. P.; DI FIORE, A. Ateles marginatus. The IUCN Red List of Threatened Species. Version 2015.2, 2008. Disponível em: <www.iucnredlist.org>. Acesso em: 28 jun. 2015.

MOURA, A. S.; CORREA, B. S.; PÁDUA, L. M.; MORÁleS, A. M. A. Registro documentado de Gavião-real, Harpia harpyja, para Guarantã do Norte, Mato Grosso. Atualidades Ornitológicas, v. 168, p. 26, 2012.

MYERS, N.; MITTERMEIER, R. A.; MITTERMEIER, C. G.; FONSECA, G. A. da; KENT, J. Biodiversity hotspots for conservation priorities. Nature, v. 403, n. 6772, p. 853-858, 2000.

PAGLIA, A. P.; FONSECA, G. A.; RYLANDS, A. B.; HERRMANN, G.; AGUIAR, L. M.; CHIARELLO, A. G.; LEITE, Y. L. R.; COSTA, L. P.; SICILIANO, S.; KIERULFF, M. C. M.; MENDES, S. L.; TAVARES, V. C.; MITTERMEIER, R. A.; PATTON, J. L. Lista Anotada dos Mamíferos do Brasil. 2. ed. Belo Horizonte: Conservação Internacional do Brasil, 2012. (Occasional Papers in conservation biology, 6).

PIMENTA, F. E.; SILVA JÚNIOR, J. S. An update on the distribution of Primates of the Tapajós-Xingu interfluvium, Central Amazonia. Neotropical Primates, v. 13, n. 2, p. 25-30, 2005. 
RABELO, R. M.; SILVA, F. E.; VIEIRA, T.; FERREIRA-FERREIRA, J.; PAIM, F. P.; DUTRA, W.; SOUZA E SILVA JÚNIOR, J.; VALSECCHI, J. Extension of the geographic range of Ateles chamek (Primates, Atelidae): evidence of river-barrier crossing by an Amazonian primate. Primates, v. 55, n. 2, p. 167-171, 2014.

RYLANDS, A. B.; KIERULFF, M. C. M. Sapajus libidinosus. The IUCN Red List of Threatened Species. Version 2015.2, 2015. Disponível em: <www.iucnredlist.org>. Acesso em: 20 jun. 2015.

RYLANDS, A. B.; SILVA JR., J. S. Mico emiliae. The IUCN Red List of Threatened Species. Version 2015.2, 2008. Disponível em: <www.iucnredlist.org>. Acesso em: 28 jun. 2015.

TERBORGH, J. Keystone plant resources in the tropical forest. In: SOULÉ, M. E. (Ed.). Conservation biology: the science of scarcity and diversity. Massachusetts: Sinauer associates, 1986. p. 330-344.

VAN ROOSMALEN, M. G. M.; KLEIN, L. L. The spider monkeys, Genus Ateles. In: MITTERMEIER, R. A.; RYLANDS, A. B.; COIMBRA-FILHO, A. F.; FONSECA, G. A. B. (eds). Ecology and behavior of neotropical primates. Washington: Editor, 1988. v. 2. p. 455-539.

VEIGA, L. M.; FERRARI, S. F. Callicebus moloch. The IUCN Red List of Threatened Species. Version 2015.2, 2008. Disponível em: <www.iucnredlist.org>. Acesso em: 28 jun. 2015.

ZAMPAULO, R. A. Diversidade de invertebrados cavernícolas na região cárstica de Arcos, Pains e Doresópolis (MG): subsídios para a determinação de áreas prioritárias para conservação. 2010. Dissertação do Programa de Pós-Graduação em Ecologia Aplicada. Universidade Federal de Lavras, 2010.

\section{Histórico editorial:}

Submetido em: 17/06/2016

Aceito em: 17/03/2017 
Como citar:

ABNT

MOURA, A. S. de; MACHADO, F. S.; CORREAA, B. S.; FONTES, M. A. L. New records to three Neotropical primates to Minas Gerais and Mato Grosso States and small expansion of occurrence area to Cebus libidinosus Spix, 1823. Revista Agrogeoambiental, Pouso Alegre, v. 10, n. 1, p. 95-104, jan./mar.

Doi: http://dx.doi.org/10.18406/2316-1817v10n120181072

APA

MOURA, A. S. de, MACHADO, F. S., CORRÊA, B. S. \& FONTES, M. A. L. (2018). New records to three Neotropical primates to Minas Gerais and Mato Grosso States and small expansion of occurrence area to Cebus libidinosus Spix, 1823. Revista Agrogeoambiental, 10 (1), 95-104.

Doi: http://dx.doi.org/10.18406/2316-1817v10n120181072

$\underline{\text { ISO }}$

MOURA, A. S. de; MACHADO, F. S.; CORREEA, B. S. e FONTES, M. A. L. New records to three Neotropical primates to Minas Gerais and Mato Grosso States and small expansion of occurrence area to Cebus libidinosus Spix, 1823. Revista Agrogeoambiental, 2018, vol. 10, n. 1, pp. 95-104. Eissn 2316-1817.

Doi: http://dx.doi.org/10.18406/2316-1817v10n120181072

VANCOUVER

Moura AS de, Machado FS, Corrêa BS, Fontes MAL. New records to three Neotropical primates to Minas Gerais and Mato Grosso States and small expansion of occurrence area to Cebus libidinosus Spix, 1823. Rev agrogeoambiental. 2018 jan/mar; 10(1): 95-104.

Doi: http://dx.doi.org/10.18406/2316-1817v10n120181072 